\title{
LIVER ABSCESS CAUSED BY Ascaris lumbricoides: CASE REPORT
}

\author{
Análida Elizabeth PINILLA(1), Myriam Consuelo LÓPEZ(2),Orlando RICAURTE(3), Blanca CASTILLO(1), Martha Isabel MURCIA(4), \\ Rubén Santiago NICHOLLS(2,5), Sofía DUQUE(2,5), \& Luis Carlos OROZCO(6)
}

\begin{abstract}
SUMMARY
A case is reported of a woman who lived in a rural area with a chronic illness that consisted of weight loss and abdominal pain in the epigastrium and upper right quadrant. The initial diagnosis was a mass in the liver, which was later, demonstrated, both by direct and histological examination, to be an abscess caused by Ascaris lumbricoides. Eggs of Ascaris lumbricoides and abundant CharcotLeyden Crystals were found.
\end{abstract}

KEYWORDS: Liver abscess; Ascaris; Amebiasis; Diagnosis; Colombia.

\section{INTRODUCTION}

The case presented here is one of the cases included in a research project on etiology of liver abscess at the San Juan de Dios Hospital in Santafé de Bogotá, Colombia. During a four-year period, cases of infectious liver abscess have been included in the study. The most frequent cause is Entamoeba histolytica, followed by pyogenic bacteria and sporadic cases of abscesses caused by Mycobacterium tuberculosis. The case reported here is the only one so far which has been caused by Ascaris lumbricoides.

\section{CASE REPORT}

A 54-year-old woman, coming from the rural area of the municipality of Velez, in the department of Santander, Colombia, was referred to the hospital for study because of a mass in the left lobe of the liver. She had a history of a chronic illness of several months duration with nonquantified weight loss and abdominal pain in the upper right half, which was associated to persistent vomiting. An ultrasound study revealed a hypo echoic lesion of irregular borders, $6 \mathrm{~cm}$ in diameter, located in the lateral segment of the left lobe. No other symptoms were present. She had undergone a cholecystectomy one year before which complicated with a peritoneal infection for which she received antimicrobial therapy.

Upon admittance she had febrile peaks of up to $38{ }^{\circ} \mathrm{C}$, without tachycardia or tachypnea. The cardiopulmonary examination was normal, no visceral enlargement was found but abdominal tenderness was present on examination of the epigastrium. The laboratory results were as follows: Hemogram: $\mathrm{Hb}: 11.7 \mathrm{~g} / \mathrm{dl}$, hematocrit: $34.5 \%$, erythrocyte sedimentation

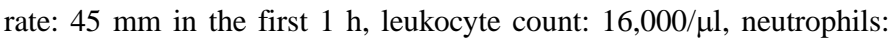
$66 \%$, eosinophils: $17 \%$; prothrombin time: 12.1 seconds, total bilirubin:
$0.7 \mathrm{mg} / \mathrm{dl}$; direct bilirubin: $0.2 \mathrm{mg} / \mathrm{dl}$. AST: $47 \mathrm{IU} / \mathrm{L}$, ALT: $44 \mathrm{IU} / \mathrm{L}$, alkaline phosphatase $127 \mathrm{mg} / \mathrm{dl}$. Glycemia and kidney function tests were within normal limits.

A chest X-ray was found to be normal. An abdominal CT scan (Fig. 1) revealed an increase in the size of the left lobe of the liver with a heterogeneous alteration of its echogenicity, but no clear image of mass or liquid collection could be defined. On October 8 of 1999, a hypo echoic lesion, $6 \mathrm{~cm}$ in diameter and with irregular shape was punctured and biopsied under ultrasonographic observation. Approximately $8 \mathrm{ml}$ of purulent material was obtained. The first culture of this material showed abundant Gram-negative bacilli and scarce Gram positive cocci, with an intense leukocyte reaction. Coagulase negative staphyloccoci, Serratia sp and quinolone sensitive $E$. coli was recovered from cultures. Because of these results the patient was prescribed a 10-day treatment with ciprofloxacin and clindamycin. Three blood cultures for aerobic and anaerobic bacteria were negative, as well as antibody tests for $E$. histolytica, then the differential diagnosis of the lesion included pyogenic abscesses; therefore, a second therapeutic puncture was done. Upon direct examination of the material obtained, eggs of Ascaris lumbricoides were found together with abundant Charcot-Leyden crystals (Fig. 2 and 3) and scarce Gram-positive cocci with intense neutrophilic reaction. Mebendazole was prescribed. Upon histological examination, a dense lymphocytic and histiocytic infiltrate was observed in the liver tissue, with neutrophils, abundant eosinophils and local fibrosis. The great number of eosinophils observed suggested the presence of parasites. Later, a sample of clear creamy green liquid obtained from the abscess was received for histopathological study. This sample was processed as a tissue sample, cellular debris, abundant eosinophils, Charcot-Leyden crystals and Ascaris lumbricoides eggs were observed.

(1) Internal Medicine Department. Universidad Nacional de Colombia, Bogotá

(2) Public and Tropical Health Department, Instituto de Salud en el Trópico, Universidad Nacional de Colombia

(3) Pathology Department, Universidad Nacional de Colombia

(4) Microbiology Department, Universidad Nacional de Colombia

(5) Instituto Nacional de Salud, Bogotá. Colombia

(6) Universidad Industrial de Santander, Colombia

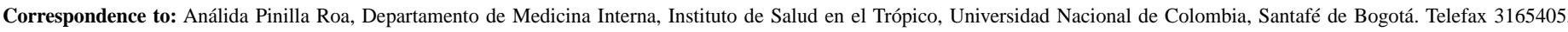
apinillaroa@hotmail.com and apinilla@supercabletv.net.co 


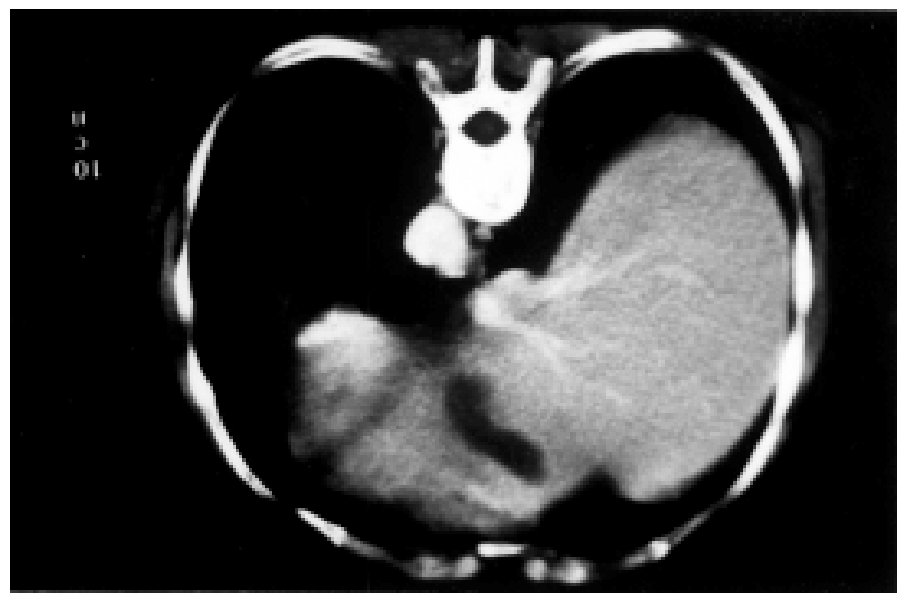

Fig. 1 - Abdominal CT scan revealed in the left lobe of the liver a heterogeneous alteration but no clear image of mass or liquid collection.

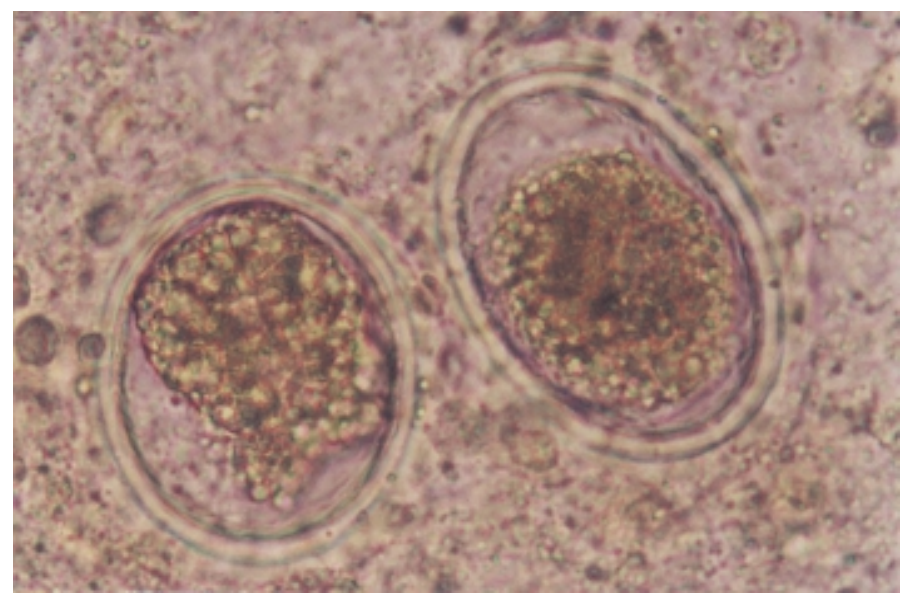

Fig. 2 - Eggs of Ascaris lumbricoides of liquid obtained from the hepatic abscess.

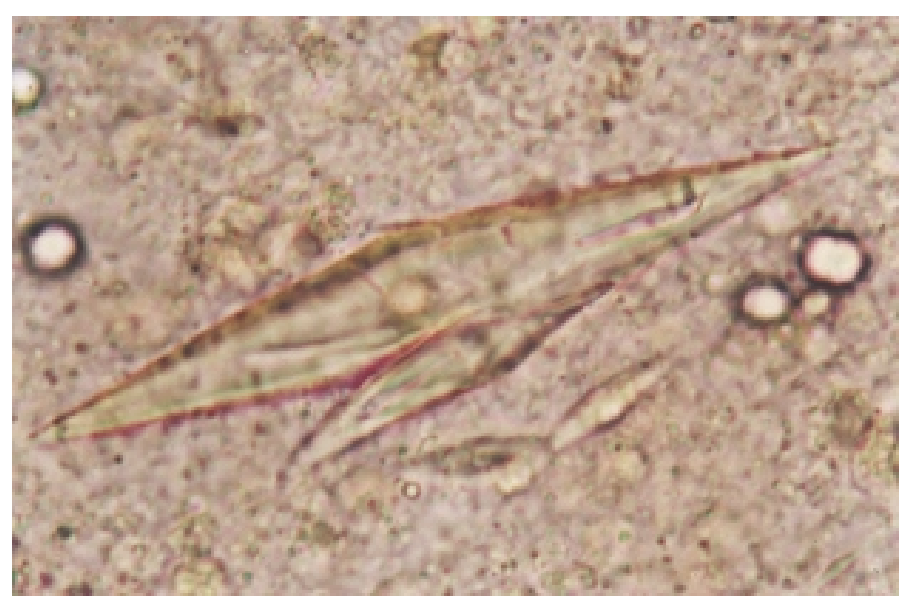

Fig. 3 - Charcot Leyden Crystals of liquid obtained from the hepatic abscess.

\section{DISCUSSION}

The diagnosis of liver abscess can be suspected clinically, but to confirm it and determine its etiology several kinds of exams are required, including chest X-ray, ultrasound study, immunodiagnostic tests, microbiological tests and direct examination. Ultrasound is the most frequently used imaging study. CT scan and magnetic resonance are less frequently employed. However, the demonstration of the etiologic agent must always be sought.

Liver abscess is relatively frequent, the amebic liver abscess has been more frequent than the pyogenic liver abscess in Colombia. Despite all the diagnostic methods available nowadays, it is not always easy to determine the etiological diagnosis and thus empirical treatments directed against both bacteria and Entamoeba histolytica are usually prescribed with very variable length of hospital stay ${ }^{1,2,11,16,18}$.

The diagnosis of liver abscess is usually considered in a patient with symptoms such as weight loss, weakness, general malaise or fever, and abdominal pain usually in the right upper quadrant, which may radiate to the epigastrium or right flank. Laboratory exams may reveal alteration of the liver function tests, leukocytosis with neutrophilia, and increase in the erythrocyte sedimentation rate. A chest X-ray shows elevation of the right hemidiaphragm, and it is possible to find parenchymal involvement of the inferior lobe of the right lung either with or without pleural effusion on the same side. Ultrasound examination reveals hypo echoic lesions with variable numbers, shapes and locations.

Infectious liver abscesses have a diverse etiology. Amebic liver abscess (ALA) is the most frequent one showing all the clinical and laboratory features described above with a positive serology test for antibodies against $E$. histolytica, either the immunodiffusion test or the ELISA test. The pyogenic liver abscess is clinically indistinguishable from the amebic liver abscess, but both serology tests for antibodies against $E$. histolytica are negative and blood cultures are positive. In the abscess fluid can be found bacterias which can be demonstrated with Gram's stain, positive cultures if no previous antimicrobial therapy has been initiated, and other possible causal agents of liver abscess such as Mycobacterium tuberculosis, fungus and parasites ${ }^{3,17}$.

Percutaneous needle aspiration guided by either ultrasound or CT scan is indicated only for therapeutic and diagnostic purposes in order to identify the etiological agent and establish the specific therapy when amebic etiology have been discarded. The first step is the direct smear to investigate not only bacteria but also other possible etiological agents, such as in the case reported here. By the contrary, in cases of amebic liver abscess the percutaneous needle aspiration is seldom recommended. Its indications are very controversial and nowadays are restricted to the following: 1. No evidence of clinical improvement after 48-72 hours of amebicidal treatment; 2. Possibility of an abscess of combined etiology; 3. Abscesses of great size located in the left lobe, because of the risk of draining to the pericardium, and 4. Patients with liver abscess and negative serology tests for E. histolytica or when performing the serological tests are impossible $8,15,17,19$.

Nowadays, the liver ultrasound is the best and most frequently employed method, because it is cheap, non-invasive, non-irradiating and very comfortable for the patient; also, it has the advantage over isotope 
methods that it clearly allows the differential diagnosis between solid and liquid content ${ }^{6}$. This is usually the initial study in the diagnostic process of this disease; it must include both the gallbladder and the pancreas in order to avoid overlooking an unexpected location of the abscess. It can reveal hypo echoic areas of more than $1 \mathrm{~cm}$ diameter. CT scan should only be employed when the ultrasound examination of the liver is not conclusive. The CT scan has a sensitivity of $95 \%$ for a single abscess and of $100 \%$ for multiple abscesses and it can reveal lesions of at least $0.5 \mathrm{~cm}$ in diameter ${ }^{4,8,14}$.

Human helminthiases are amongst the most prevalent parasitic infections, and of them infection by Ascaris lumbricoides is the most frequent. The intestinal infection by Ascaris lumbricoides is the most frequent and widespread of all the human helminthiases; its prevalence is high in areas where poverty, poor housing conditions, overcrowding, and deficient environmental sanitation are present ${ }^{4,10}$. In the last national study on prevalence of intestinal parasites in Colombia, carried out in 1980, the frequency of infection with this nematode was between $19.8 \%$ and $38.9 \%$. Despite the high incidence of intestinal ascaridiasis in tropical countries, ectopic forms are rare, such as in the appendix, the pancreatic duct, the bile duct or hepatic parenchyma ${ }^{13,21}$. The obstruction of the biliary tree causes cholecystitis, jaundice, pancreatitis, cholangitis, and liver abscess ${ }^{12}$. This parasitic infection has bizarre forms, such as the ascariasis of the liver, which can be caused by adult worms and eggs located in the bile ducts or in the liver parenchyma, or it may also be due to larvae remaining in the hepatic parenchyma during their life cycle. The clinical pictures described include hepatitis, liver, perihepatic, subphrenic and pulmonary abscesses, cholangitis, cholecystitis, bile duct perforation, filtrating biliary peritonitis, septicemia, pileflebitis and thrombosis of the pulmonary artery. Other rare form is hepatic nodules with marked infiltration of eosinophils such as reported in a case of a 35-year old man who had eosinophilia, an elevated level of serum IgE, and anti-parasitic antibodies ${ }^{22}$. In fact, the liver abscess caused by Ascaris lumbricoides has no distinctive clinical features to allow its differential diagnosis with liver abscesses caused by other microorganisms $s^{7,18,21}$.

Most of the cases reported so far have been diagnosed during surgery or during autopsy. The specific diagnosis of Ascaris in the liver is established by the observation of eggs on direct or histological examination. To identify the eggs in tissue is not difficult, usually the eggs lose their external albuminoid shells, and only conserve their chitinous membrane ${ }^{10}$. The broken or collapsed eggs are always found within the abscess or the necrotic substance. When the female penetrates deeply into the bile ducts, it lays eggs, which are carried into the liver parenchyma, leading to the production of a foreign body granuloma, known as granulomatous hepatitis. Another possibility is the production of a liver abscess when the adult parasite dies inside the liver, giving rise to a necrotic focus, which can become subsequently infected. The parasite migrates with bacteria causing obstruction of the bile duct with supurative cholangitis. The eggs or parasite fragments in the bile ducts can become a nucleus which gives rise to either coledocian or intrahepatic stones ${ }^{7}$.

Peripheral eosinophilia, which in the case described here was $17 \%$, and tissue eosinophilia, is part of the immune response of the host against the parasite. Eosinophilia is greater when there is larval migration or when eggs are deposited within the liver tissue, as in the case reported here. Eosinophilia in the liver tissue suggests, as possible diagnoses, a reaction to drugs mediated by an immediate hypersensitivity mechanism, an inflammatory granulomatous foreign body type reaction, a parasitic disease or eventually proximity to involvement by Hodgkin's lymphoma. In this case, a liver mass associated with anemia, non-quantified weight loss in a chronic illness and age of the patient suggests at the first time malignancy; nevertheless the ultrasound and CT scan demonstration of an abscess suggested more the possibility of an associated parasitic disease which was demonstrated by direct examination and cytological study. Finally, it is important to remember that the immune response to Ascaris is mediated by both cellular and humoral immune mechanisms, through $\operatorname{IgE}$ and $\operatorname{IgM}^{5,20}$.

\section{RESUMEN}

\section{Absceso hepático por Ascaris lumbricoides: reporte de un caso}

Se presenta el caso de una mujer que vivía en zona rural con una enfermedad crónica consistente en pérdida de peso y dolor epigástrico y del cuadrante superior derecho del abdomen. El diagnóstico inicial fue de masa hepática izquierda a estudio, demostrándose luego por frotis directo y por histopatología que se trataba de un absceso hepático por Ascaris lumbricoides. Huevos de Ascaris lumbricoides y abundantes cristales de Charcot-Leyden fueron encontrados.

\section{ACKNOWLEDGEMENTS}

The authors wish to acknowledge the Research Division of the National University of Colombia, which has supported financially the project number 709150. The authors thank to Ivonne Anzola, clinical laboratory professional of the Infectology Unit of the San Juan de Dios Hospital in Bogotá, Colombia.

\section{REFERENCES}

1. Álvarez, W.; CUEllo, J.; TROUT, G. et al. - Absceso hepático amebiano. Acta méd. colomb., 17 (supl.): 301, 1992.

2. ARGUELlO J., M. \& GÓMEZ V., R.D. - Amibiasis hepática. In: ARGUELLO J., M. \& GOMEZ V., R.D. De la Entamoeba histolytica a la enfermedad amibiana. Santafé de Bogotá, Laboratorios Síntesis; División Gastrointestinal, 1992. p. 104-130.

3. BANDRES, M.; BURSTEIN, E.; CASA, J. \& VERONA, R. - Absceso hepático tuberculoso: descripción de un caso y discusión de la literatura. Rev. Gastroent. Perú., 14: 233-237, 1994.

4. BEJARANO C., M. - Ascariasis: complicaciones hepatobiliares, Hospital Universitario San José, Popayán, 1984-1993. Colombia. méd., 26: 55-60, 1995.

5. BHARATHA, S. - Ascariasis. In: CONNOR, D.H.; CHANDLER, F.N.; SCHWARTZ, D.A. et al., ed. Pathology of infectious diseases. Stamford, Appleton \& Lange, 1997. v. 2, p. 1321-1326.

6. BLANCO Q., F.; NOVELlA A., B.; SANCHEZ M., P. \& SANZ S., J. - Descriptive study of 39 cases of hepatic abscess of pyogenic and amebic origin. An. Med. interna, 12 : 477-484, 1995.

7. BOTERO, D. \& RESTREPO, M. - Parasitosis intestinales por nematodos. In: BOTERO, D. \& RESTREPO, M. Parasitosis humanas. 3. ed. Medellín, Corporación para Investigaciones Biológicas, 1998. p. 89-99.

8. BRANUM, G.D.; TYSON, G.S.; BRANUM, M.A. \& MEYERS, W.C. - Hepatic abscess Changes in etiology, diagnosis, and management. Ann. Surg., 212: 655-662, 1990. 


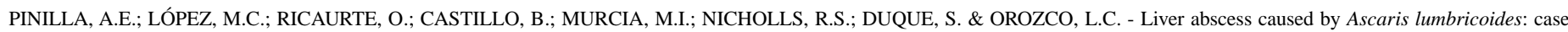
report. Rev. Inst. Med. trop. S. Paulo, 43(6):343-346, 2001.

9. CORREDOR, A.; ARCINIEGAS, E.; HERNÁNDEZ, C.A. et al. - Parasitismo intestinal. Santafé de Bogotá, Instituto Nacional de Salud, 2000.

10. FOGAÇA, H.S.; OLIVEIRA, C.S.; BARBOSA, H.T.; LANFREDI, R.M. \& CHAGAS, V. - Liver pseudotumor: a rare manifestation of hepatic granulomata caused by Ascaris lumbricoides ova. Amer. J. Gastroent., 95: 2099-2101, 2000.

11. GÓMEZ, J.M. - Caso clínico de la Unidad de Medicina Interna: absceso hepático piógeno. Rev. Fac. Med. (Bogotá), 41: 99-104, 1993.

12. HOLCOMBE, C. - Surgical emergencies in tropical gastroenterology. Gut, 36: 9-11, 1995.

13. KHUROO, M.S. - Ascariasis. Gastroent. Clin. N. Amer., 25: 553-577, 1996.

14. MCDONALD, K.L. \& DAVANI, M. - The rim in hepatic abscess: case report and review of the literature. J. nucl. Med., 38: 1282-1283, 1997.

15. MISCHINGER, H.-J.; HAUSER, H.; RABL, H. et al. - Pyogenic liver abscess: studies of therapy and analysis of risk factors. Wld. J. Surg., 18: 852-858, 1999.

16. PÉREZ, J.; SUÁREZ, A; MARTÍNEZ, L. \& SALEJ, J. - Métodos serológicos en el diagnóstico del absceso hepático amibiano. Acta méd colomb., 15(supl): 264, 1990.
17. PIGGOTT, J.; HANSBARGER Jr., E.A. \& NEAFIE, R.C. - Human ascariasis. Amer. J. clin. Path., 53: 223-234, 1970.

18. PINILLA, A.E.; LASTRA, G.; CAMACHO, G. et al. - Absceso hepático en el Hospital San Juan de Dios de Bogotá. In: CHALEM, F. \& CASASBUENAS, J., ed. - XIV Curso Anual. Departamento de Medicina Interna, Hospital San Juan de Dios, Universidad Nacional de Colombia. Santafé de Bogotá, Ediciones Acta Médica Colombiana, 1996. p. $125-141$.

19. RAVDIN, J.I. - Amebiasis. Clin. infect. Dis., 20: 1453-1466, 1995.

20. RODRÍGUEZ T., G.; RICAURTE, O. \& JARAMILLO DE NARANJO, P. - Granulomas infecciosos del hígado. Biomédica, 9: 32-57, 1989.

21. SEVEREN, M.V.; LENGELE, B.; DUREUIL, J.; SHAPIRA, M. \& DIVE, Ch. - Hepatic ascaridiasis. Endoscopy, 19: 140-142, 1987.

22. SHUICHI, A.; MASUMOTO, A; UNOKI H. et al. - Transient multiple hepatic nodules with marked infiltration of eosinophils caused by ascariasis. Amer. J. Gastroent., 92: 897-898, 1997.

Received: 7 June 2000

Accepted: 26 September 2001 